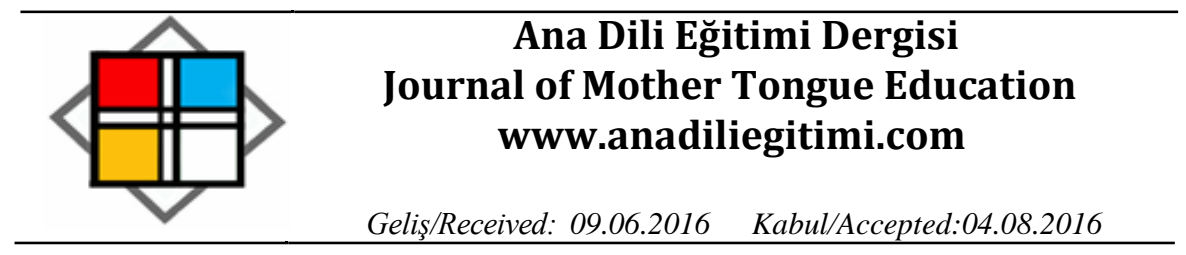

\title{
Türkçe Eğitimi Bölümlerindeki Öğretim Elemanlarının Niteliğine İlişkin Bir Araştırma1
}

\author{
Erkan ÇER ${ }^{2}$
}

\begin{abstract}
Öz
Bu çalışma, Türkçe eğitimi bölümlerinde görev yapan öğretim elemanlarının genel niteliklerini belirlemeyi amaçlamaktadır. Bu amaç doğrultusunda, nitel bir araştırma deseni kullanılarak Türkçe eğitim bölümlerinde yer alan öğretim elemanlarının nitelikleri incelenmiştir. Doküman incelemesi yöntemi kullanılan bu çalışmanın veri kaynağını, Türkçe eğitimi bölümlerindeki öğretim elemanlarının uzmanlık alanları ve akademik unvanları oluşturmaktadır. Bu yönüyle, ilk olarak "Öğrenci Seçme ve Yerleştirme Sistemi Merkezi" (ÖSYS) 2015 yılı yükseköğretim programları ve kontenjanları kılavuzu incelenerek "Türkçe Öğretmenliği"ne sahip 62 üniversite belirlenmiştir. İkinci olarak, belirlenen üniversitelere "Yüksek Öğretim Kurulu" (YÖK)'ün bilgisunar adresinden ulaşılarak bölümlerdeki öğretim elemanlarına ilişkin araştırma kapsamında ele alınan bilgilere ulaşılmış ve bu bilgiler "Yüksek Öğretim Kurulu Ulusal Tez Merkezi"nden elde edilen verilerle de desteklenmiştir. Araştırmaya konu olan verilere ise içerik çözümlemesi türlerinden sıklık çözümlemesi tekniği uygulanmıştır. Bu yüzden veriler, bilgisayar ortamına aktarılmış ve SPSS 23 programı aracılığıyla Türkçe eğitimi bölümlerinde yer alan öğretim elemanlarının üniversitelere göre dağılımları, Türkçe eğitimcisi olup olmadıkları, akademik unvanları ve cinsiyetleri ortaya çıkarılmıştır. Bu çalışma sonucunda ise, Türkiye'de 193 üniversite içinde toplam sayısının 62 olduğu Türkçe eğitimi bölümlerinde yer alan öğretim elemanlarından ( $n=335)$ salt 123 (\% 36.7)'ünün Türkçe eğitimcisi, 150 (\% 44.8)'sinin Türk Dili ve Edebiyatı uzmanı ve 62 (\% 18.5)'sinin farklı dallarda alan uzmanı olduğu görülmüştür. Bu durum, Türkçe eğitimi bölümlerinde yer alan Türkçe eğitimcisi sayısının oldukça yetersiz olduğunu ortaya koymaktadır.
\end{abstract}

Anahtar Sözcükler: Türkçe eğitimi bölümü, öğretim elemanları, nitelik

\section{A Study on the Quality of Instructors in the Departments of Turkish Language Teacher Education}

\begin{abstract}
This study aims to determine the general quality of instructors serving in the Departments of Turkish Language Teacher Education. For the purpose of this study, the qualities of the instructors in the Departments of Turkish Language Teacher Education were determined using qualitative research design. Fields of specialization and academic titles of the instructors formed the source of the data in this study for which document analysis method was used. Firstly, 62 universities, which had "Department of Turkish Language Teacher Education" listed in the 2015 guide of higher education programs and quotas of the Student Selection and Placement System Center (OSYS), were identified. Secondly, the information about the instructors was obtained through the "info provider" section of Council of Higher Education (YOK) official website, and this information was supported by the data obtained with the Council of Higher Education National Dissertation Center.
\end{abstract}

\footnotetext{
${ }^{1}$ Bu araştırma, Muğla Sıtkı Koçman Üniversitesi tarafından düzenlenen, "7. Uluslararası Türkçenin Eğitimi ve Öğretimi Kurultayı"nda sözlü bildiri olarak sunulmuştur. Muğla: 19-21 Haziran 2014.

${ }^{2}$ Yrd. Doç. Dr, Amasya Üniversitesi, Eğitim Fakültesi, Türkçe Eğitimi Bölümü, Amasya.

E-posta: erkan.cer@gmail.com
} 
The data for this study were analyzed using frequency analysis which is a type of content analysis. For this reason, the data were transferred into a computer, and distribution, academic titles, and genders of the instructors, and whether or not they were Turkish Language Education experts were determined, using SPSS version 23. The result showed that, of the instructors in the Departments of Turkish Language Teacher Education, in 62 of 193 universities, 123 (\% 36.7) were Turkish Language Education experts, 150 (\% 44.8) were Turkish Language and Literature professionals, and 62 (\% 18.5) were professionals from other fields of study. This finding shows that the number of Turkish Language Education experts in the Departments of Turkish Language Teacher Education is rather inadequate.

Key Words: department of Turkish Language Teacher Education, instructors, quality

\section{Giriş}

Türkçe öğretiminin başat amacı, anlama ve anlatma becerileri gelişmiş düşünen, duyarlı bireyler yetiştirmektir (Sever, Kaya ve Aslan, 2011: 12; Göğüş, 1993: 6; Özbay, 2006: 16; Aslan, 2007a; Çotuksöken, 2010: 14; Kavcar, 2002: 12; Sever, 2003: 28; Göçer, 2014: 24). Bu amacın gerçekleşebilmesi için Türkçe eğitiminin alanında uzmanlaşmış Türkçe eğitimcilerle yürütülmesi gerekmektedir. Başka bir söyleyişle, öğrencilerin dilsel becerilerinin yetkinleşmesi, duygu ve düşünce evrenlerinin gelişmesi, dil bilinci ve duyarlığı kazanması, Türkçe eğitiminin alanında uzman eğitimcilerle yürütülmesine bağlıdır (Sever, 2002: 194). Böylelikle öğretmen adayları hem dinleme, konuşma, okuma, yazma olarak adlandırılan dilsel becerileri geliştirmeye yönelik eğitim ortamlarının nasıl kurgulanması gerektiğine yönelik bilgi ve becerileri kazanabilirler hem de çocuğun üst düzey düşünmesine ve insana, yaşama, doğaya yönelik duyarlı olmasını sağlayacak düzeye uygun nitelikli metinlerin okuma, konuşma, dinleme ve yazma etkinlikleri için birer uyaran olduğunu öğrenebilirler.

Türkçe öğretmeni adayının aldığı eğitimin niteliği, Türkçe öğretiminin niteliğini etkileyebilir. Özellikle derslerin alan dışındaki öğretim elemanlarınca yürütülmesi, öğretmen adaylarının Türkçenin öğretimine ilişkin bilgi ve becerilerini de olumsuz yönde etkileyebilir. Bu durum, öğretmen adaylarının anlama ve anlatma becerilerini geliştirici etkinliklerle yeterince karşılaşmamalarına yol açmakla birlikte onların ders ortamlarına yönelik dilsel etkinliklerle tasarlanmış eğitim durumlarıyla da tanışmamalarına neden olabilir. Daha açık bir anlatımla, Türkçe öğretmeni adaylarının yeterince alan eğitimcileriyle karşılaşmaması, bu alanın beceriden çok bilgi dersi gibi algılanmasına (Kavcar, 2002: 15; Özdemir, 2002: 11), dilsel becerilerin geliştirilmesinde bütünsellik anlayışının yaşama geçirilememesine (Sever, 2011; Aslan, 2007a), öğretimde metinden kopuk, kuramsal ve soyut dilbilgisi araştırmaları yapılmasına (Dilidüzgün, 2003), dilsel becerileri kazandırma sürecinde öğrencinin gelişim düzeyinin ve yetiştiği toplumsal çevrenin göz önünde bulundurulmamasına (Çer, 2016a, 2016b; Aslan, 2007b) salt ders kitabına bağımlı kalınarak çok uyaranlı eğitim ortamlarının yaratılamamasına (Turhan, 2016), genellikle öğretici metinlere yer verilerek dersin duyarlık kazandırma boyutunun göz ardı edilmesine neden olabileceği gibi Türkçe öğretiminin başat sorunlarını da ortaya çıkartabilir. 
Üniversite eğitimi sürecinde Türkçe, Matematik, Fen Bilgisi, Müzik eğitimi bölümlerinde, öğretim elemanlarının niteliği üzerine yapılan araştırmalar incelendiğinde, öğretmen adaylarının öğretim elemanlarını nitelikli ve yeterli bulmadıkları (Baştürk, 2011; Yeşil ve Özbek, 2008; Erginer ve Dursun, 2005), öğretim yöntem, teknik ve stratejileri kullanma becerileri açısından, iletişim yönünden, ölçme ve değerlendirme konusunda yeterli düzeyde olmadıkları (Arslantaş, 2011: 502; Şen ve Erişen, 2002), dersleri yürütürken ilgi çekici konulara yer vermedikleri, not tutturma, öğrencileri derse hazırlıklı gelmeye özendirmeme gibi öğrenme-öğretme sürecinde etkili olmayan uygulamalara yer verdikleri (Aksu, Çivitçi ve Duy, 2008), eğitim-öğretim etkinliklerinde yeterli olmadıkları (Murat, Arslantaş ve Özgan, 2006:271; Köseoğlu, 1992: 74), öğretim araç ve gereçleri konusunda öğrencilere yeteri kadar sorumluluk vermedikleri (Arslantaş, Cinoğlu ve Yıldız, 2013: 10) belirlenmiştir. Bu durum, öğrencilerin yükseköğretim sürecinde aldıkları eğitimin niteliğini düşürmekle birlikte memnuniyetlerini de olumsuz bir biçimde etkilemekte (Ekinci ve Burgaz, 2007; Özçakır Sümen ve Çağlayan, 2013: 268) ve öğrencilerin kendilerine yönelik yeterliklerinde orta ve iyi gibi nitelemelerde bulunmalarına neden olmaktadır (Seferoğlu, 2004b: 139). Bu yönüyle, Türkçe eğitimi bölümlerinde yer alan öğretim elemanlarının yeterlik düzeylerinin ortaya çıkarılması gerekmektedir.

Bu çalışma, ilk olarak Türkçe eğitimi bölümlerinde yer alan öğretim elemanlarının yeterliklerini öğrenci görüşleri üzerinden değerlendirmek yerine doğrudan öğretim elemanlarının niteliğiyle ilişkilendirmiştir. Çünkü bu konuyla ilgili yapılan araştırmalar salt öğrenci görüşleri doğrultusunda öğretim elemanlarının yeterlik düzeylerini ortaya koymaktadır (Aksu, Çivitçi ve Duy, 2008; Arslantaş, 2011; Arslantaş, Cinoğlu ve Yıldız, 2013; Baştürk, 2011; Ekinci ve Burgaz, 2007; Erginer ve Dursun, 2005; Köseoğlu, 1992; Murat, Arslantaş ve Özgan, 2006; Özçakır Sümen ve Çağlayan, 2013; Seferoğlu, 2004b; Şen ve Erişen, 2002; Yeşil ve Özbek, 2008). Oysa bu çalışma, Türkçe öğretmeni adaylarının alan eğitimine yönelik bilgi ve becerilerini, Güzel ve Kurudayıoğlu ve Tüzel (2010) ile Kurudayıoğlu ve Yılmaz'ın (2015) yaptıkları çalışmalarla birlikte Türkiye'de ilk kez öğretim elemanlarının üzerinden değerlendirmektedir. Böyle bir değerlendirme, hem Türkçe eğitimi bölümlerinin akademik yapısıyla ilgili genel bir görüş ortaya koyabilir hem de Türkçe öğretmeni adaylarının aldıkları öğretiminin niteliğini belirleyebilir. İkinci olarak, bu çalışma öğretim elemanlarının niteliği üzerine yapılan araştırmalardan farklı olarak, Türkçe eğitimi bölümlerinde yer alan öğretim elemanlarının üniversitelere göre dağılımlarını ortaya koymaktadır. Bu durum, Türkçe öğretmeni adaylarının Türkçe eğitimcisiyle karşılaşma düzeylerinin ortaya çıkarılmasına katkı sağlayabilir. Son olarak, bu çalışma eğitim fakültelerinin yeniden yapılandırılma sürecinde Türkçe eğitimi bölümlerinin içerik ve öğretim üyesi bakımından değişecek olması (Milliyet, 2016), bu bölümlerde yer alan öğretim kadrolarının niteliklerinin ileride karşılaştırmalı bir değerlendirme yapılabilmesi için ortaya çıkarılmasını gerekli kılmaktadır. 
Bu çalışmanın amacı, Türkçe eğitimi bölümlerindeki öğretim elemanlarının genel niteliklerini ortaya çıkarmaktır. Çünkü Türkçe öğretmeni adaylarının lisans eğitimi süresince karşılaştığı öğretim kadrosu, öğretmen adayının niteliğini doğrudan etkileyebilir. Bu durum, öğretmen adaylarının Türkçenin öğretimine ilişkin yöntem ve teknik bilgisini kazanmasına, bu bilgilerin kaynaklığında eğitimöğretim ortamlarının bilimsel ilkeler doğrultusunda düzenlemesine, eğitim durumlarının kurgulanmasına ve bu durumların uygulanmasına yönelik derslere ilişkin olarak alan eğitimcileriyle karşılaşma düzeylerini de ortaya çıkaracaktır. Böylelikle Türkçe öğretiminde yaşanan sorunların başat nedenleri de açığa çıkarılacaktır.

\section{Türkçe Öğretiminde Öğretmen Değişkeni}

Türkçe öğretiminin öncelikli sorumluluğu, öğrencilerin dinleme, okuma, konuşma ve yazma becerilerini bilimsel bir anlayışla planlı bir biçimde geliştirmek, onlara Türkçeyi doğru, bilinçli kullanma duyarlığı ve alışkanlığı kazandırmaktır. Bu sorumluluğun yerine getirilmesi, ilköğretim birinci sınıftan başlayıp sekizinci sınıfın sonuna kadar süren Türkçe öğretiminin etkili ve verimli kılınmasıyla olanaklıdır (Sever, 2003: 28). Türkçe öğretiminde böyle bir anlayışın ortaya çıkarılmasında öğretmen değişkeninin katkısı yadsınamaz. Çünkü öğretmen, öğrenmeyi öğrenci için uygun öğrenme yaşantılarını seçerek, öğrencinin çevresini, eğitimin amaçlarına ulaşmasını kolaylaştıracak biçimde ayarlayan (Ertürk, 1993: 16), düşünen, eleştiren, yaratıcı, soru soran, gelişme ve yeniliklere açık, kendini sürekli yenileyen ve işini seven (Kavcar, 1999:270), eğitimin amaçlarının gerçekleştirilmesinin yük ve sorumluluğunu büyükölçüde üzerinde taşıyan (Murat, Aslantaş ve Özgan, 2006:264), genel kültür açısından yeterli, alanlarında gerekli bilgi ve becerilere sahip ve öğretmenlik meslek bilgisi ve becerisiyle donanmış bir eğitimcidir (Şen ve Erişen, 2002: 114). Bu bakımdan, öğretmen yetiştirmeye yeterli düzeyde önem verilmesi gerekir (Karamustafaoğlu ve Özmen, 2004: 45).

Eğitim sisteminin en önemli öğesinin öğretmen olması (Kavcar, 2002b: 1) ve nitelikli bireylerin ortaya çıkmasında öğretmenin önemli yük ve sorumluluklarının bulunması (Küçükahmet, 1993: 77), öğretmen yetiştirmenin çok boyutlu ve kapsamlı bir süreç olduğunu ortaya koymaktadır. Özellikle Türkçe öğretiminin çocuklara doğru, açık ve etkili bir iletişimi gerçekleştirebilecek dilsel becerileri kazandırma; onların düşünme güçlerini geliştirme, yetkinleştirme ve toplumsallaşma süreçlerine katkıda bulunma gibi temel sorumluluklarının olması (Sever, 2011: 1), öğretmenlerin, değişim ve gelişmeyi anlayabilen, yorumlayabilen, etkililik ve nitelik gibi değer ve davranışları içselleştirmiş bireylerden oluşmasını gerekli kılmaktadır (Şen ve Erişen, 2002: 100). Daha açık bir anlatımla, öğrencilerin yoğunlaşmasını sağlayıcı etkinlikleri gerçekleştirme, öğrencilerin ilgi ve gereksinmelerine uygun öğrenme yaşantıları oluşturma, öğrencilerin dikkatlerini çekip uyanık tutabilme, istenmeyen davranışları uygun yöntem ve strateji kullanarak ortadan kaldırma, zamanı etkili kullanma vb. özellikler, 
öğretmenlerin etkililiği açısından sahip olması gereken özelliklerdir. Bununla birlikte, yeterli alan bilgisine ve genel kültür bilgisine sahip olma, temel insan ilişkileri becerisinde yeterlik ve öğretmenlik meslek bilgisi yeterliğine sahip olma, etkili bir sınıf yönetimi açısından öğretmenlerde bulunması gereken özelliklerdir (Murat, Aslantaş ve Özgan, 2006:265).

Türkçe öğretiminin niteliği, öğretmenler tarafından geliştirilir (Kavcar, 2002b: 2). Çünkü Türkçe dersleriyle kazandırılması amaçlanan davranışların birbirini bütünleyen aşamalı bir anlayışla öğrencilere edindirilmesi, öğretimin verimini etkileyen önemli bir değişkendir (Sever, 2003: 28). Bu yönüyle, öğretmen adaylarının yetiştirilmesinde, istenilen nitelikte olabilmeleri için birtakım özelliklerin saptanması gerekir. Bu özellikleri sağlayan yollardan birisi öğretmen yeterlikleridir (Seferoğlu, 2004a: 41). Bu yeterlikler, öğretmenlerin bilgi, beceri, tutum, değer, davranış gibi yönlerden sahip olmaları öngörülen özellikler ya da nitelikler bütünü olarak ifade edilmektedir. Bu yönüyle, öğretmenin sahip olması öngörülen alanlar, konu alanı, meslek ve genel kültür bilgisidir. Özellikle öğretmenin uzmanlaştığı alan bilgisi, öğrenme-öğretme sürecine ve değerlendirmeye yönelik yeterliği onun niteliğine ilişkin dönütler sunmaktadır (Saylan ve Uyangör, 1998: 36; Şişman, 2009a: 39; 2009b: 68). Çünkü nitelik açısından iyi yetişen öğretmenler, öğrenciler için olumlu öğrenme koşulları sağlayarak farklı yaş ve gelişim düzeyindeki öğrenciler için farklı yaklaşım, yöntem ve teknik uygulayabilirler.

Türkçe öğretiminde, öğretmenin rolü öğrenmeyi kolaylaştırmaktır. Bunun için öğretmen, öğrenme etkinlikleri sırasında öğrencileri dikkatle izlemeli, gereksinim duyduklarında onlara yol göstermelidir. Bireysel farklııkları da göz önünde tutarak öğrencilerin öğrenmelerini nasıl tasarlayacaklarını kolaylaştırmaları gerekmektedir. Türkçe derslerinde öğretmen; anlama (dinleme, okuma), anlatma (yazma, konuşma) ve dilbilgisi konu alanına ilişkin etkinliklerde öğrencilerine salt soru soran değil, öğrencilerine; okuduklarına, dinlediklerine eleştirel bir tutumla yaklaşma alışkanlığı kazandıran, onların metinle ilgili soru sormalarını, akıl yürütmelerini, karşılaştırma ve değerlendirme yapmalarını sağlayan kişidir (Sever, Kaya ve Aslan, 2011: 27). Bu yönüyle, Türkçe öğretiminde üst düzey düşünebilen, nitelikli metinlerin tanıklığında dersleri sürdüren, metinden yola çıkarak dilbilgisi konularını sezinleten, dilsel becerileri etkili bir biçimde geliştiren ve duyarlık eğitimi verebilen öğretmenlerin ortaya çıkmasında Türkçe eğitimi bölümlerine önemli sorumluluklar düşmektedir.

\section{Türkçe Eğitimi Bölümleri ve Öğretim Elemanları}

Türkçe öğretiminin amaçları, öğrencilerin sözlü iletişim, okuma ve yazma becerilerini geliştirmek, Türkçeyi konuşma ve yazma kurallarına uygun olarak bilinçli, doğru ve özenli kullanmalarını sağlamak, düşünme, anlama, sıralama, sınıflama, sorgulama, ilişki kurma, eleştirme, yordama, yorumlama, eleştirme, çözümleme, bireşim yapma ve değerlendirme becerilerini geliştirmek, okuduğu, 
dinlediği ve izlediğinden hareketle, söz varlığını zenginleştirerek dil zevki ve bilincine ulaşmalarını; duygu, düşünce ve hayal dünyalarını geliştirmelerini sağlamak, okuma ve yazma sevgisi ile alışkanlığını kazanmalarını sağlamak, duygu ve düşünceleri ile bir konudaki görüşlerini veya tezini sözlü ve yazııı olarak etkili ve anlaşııır biçimde ifade etmelerini sağlamak, bilimsel, yapıcı, eleştirel ve yaratııı düşünme, kendini ifade etme, iletişim kurma, iş birliği yapma, problem çözme ve girişimcilik gibi temel becerilerini geliştirmek, bilgiyi araştırma, keşfetme, yorumlama ve zihinde yapılandırma becerilerini geliştirmek olduğuna göre (MEB, 2015), bu amaçların gerçekleştirilebilmesi için Türkçe eğitimi bölümlerinde öğretim gören öğretmen adaylarının gereksinim duyulan niteliklere uygun bir biçimde yetiştirilmesi gerekmektedir. Yani, öğretmen adaylarına öğretmenliğin gerektirdiği uygulamaya dönük bilgi, beceri ve bakış açılarının kazandırılması gerekmektedir (YÖK, 2007). Bu yönüyle, Türkçe eğitimi bölümlerinin amacı, ilköğretim okullarına Türkçe dersleri verebilecek yetenekte ve donanımda Türkçe öğretmeni yetiştirebilmektir.

Öğretim elemanlarının bilgi ve becerileri, öğretmen adaylarının meslekleriyle ilgili tutumlarında önemli rol oynamaktadır (Saracaoğlu, Bozkurt, Serin ve Serin, 2004: 19). Özellikle Türkçe öğretiminde, alan eğitimcilerinin öğretmen adaylarına anlama ve anlatma becerilerine yönelik yöntem, teknik, strateji, etkinlik örnekleri ve eğitim durumlarını öğretmesi, öğretmen adayının başarısını etkilemektedir (Sever, 2002: 195). Bu bakımdan, öğretim elemanları sınıftaki tüm öğrencilerle ilgilenmeli, onların derse katılmalarını sağlamalı, sözel ve sözel olmayan davranışlarını öğrencilerin derse başarısını arttıracak bir biçimde düzenlemelidir. Bununla birlikte, öğretim elemanlarının uzmanlık alanı ile ilgili konusunu açık ve anlaşıı bir biçimde anlatması, derse hazırlıklı bir biçimde gelmesi ve öğrenci-öğretmen uyumunun çok iyi olması gerekmektedir (Ergün, Duman, Kıncal ve Arıbaş, 1999: 3). Aynı zamanda, öğretim elemanlarının öğretim görevlerini yerine getirebilmeleri için yeterli bir alan bilgisine sahip olma ve öğrencilerle etkili iletişim kurabilme becerisi, sınıf yönetimi becerisi, yeterli bir biçimde öğretim yöntem ve tekniklerini kullanma bilgi ve becerisi gibi bazı niteliklere sahip olması gerekmektedir (Arslantaş, 2011: 489). Oysa öğretmen eğitimi veren kurumlarda, öğretim elemanlarının alan eğitimine yönelik olarak bilgi ve beceri kazandırılması yerine bilim dallarının genel konuları ele alınıp işlenmektedir. Özellikle Türkçe öğretimi derslerini okutan öğretim elemanları Türk dili ve edebiyatı ile ilgili genel bilgiler vermektedir (Yılman, 1992: 265).

Güzel, Kurudayıoğlu ve Tüzel'in (2010: 460) yaptıkları araştırma sonuçlarına göre, Türkçe eğitimi bölümlerinde görev yapan 203 öğretim elemanının 47 (\% 23)'si Türkçe eğitimi alanında doktora derecesine sahipken 156 (\% 77)'si diğer alanlardan doktora derecesine sahiptir. Bununla birlikte, 26 (\% 51) üniversitedeki öğretim elemanları arasında Türkçe eğitimcisine rastlanmazken 10 (\% 19.5) üniversitede salt 1'er tane Türkçe eğitimcisine rastlanmaktadır. Kurudayıoğlu ve Yılmaz'ın (2015: 366) yaptıkları araştırma sonuçları incelendiğinde ise, Türkçe eğitimi bölümlerinde görev yapan 280 öğretim 
elemanının 100 (\% 35)'ü Türkçe eğitimi alanında doktora derecesine sahipken 180 (\% 64)'i diğer alanlardan doktora derecesine sahiptir. Aynı biçimde, 19 (\% 31) üniversitede Türkçe eğitimi alanında doktora derecesine sahip öğretim elemanına rastlanmazken 12 (\% 20) üniversitede salt 1'er tane Türkçe eğitimcisine rastlanmaktadır. Bütün bu bulgular, Türkçe eğitimi bölümlerinde öğretmen adaylarının alan eğitimcileriyle karşılaşma durumunu ortaya koymaktadır. Özellikle 2010 yılında 26 (\% 51) ve 2015 yılında 19 (\% 31) üniversitede Türkçe eğitimcisinin olmaması, öğretmen adaylarının Türkçenin eğitimine ve öğretimine ilişkin olarak yetkinleşememesine neden olabilir (Sever, 2002). Bununla birlikte, bu durum Türkçe derslerine başka alanlardan öğretim elemanlarının da girdiğinin göstergesidir. Böylelikle Türkçe öğretmeni adaylarının yeterince alan eğitimcileriyle karşılaşmaması ve bu alanın beceriden çok bilgi dersi gibi algılanması Türkçe öğretiminin sorunları olduğuna göre (Kavcar, 2002a; Özdemir, 2002; Sever, 2003), bu sorunların oluşmasının başat nedenleri daha iyi anlaşılabilir.

Türkçe eğitimi bölümlerindeki derslerin ilgili alan uzmanlarınca yürütülmesi üniversite gerçeğinin bir gereğidir. Bu bölümlerde yer alan derslerin alan dışındaki öğretim elemanlarınca yürütülmesi, Türkçe öğretiminin salt edebiyat ya da dilbilgisi odaklı görülmesine neden olabilir. Daha farklı bir söyleyişle, Türkçe eğitimi bölümlerinde, derslerin edebiyat ağılıklı olması ve edebiyat tarihine yönelik olarak öğretmen adaylarına sürekli bilgi verilmesi, onların Türkçenin öğretimine ilişkin bilgi ve becerilerini olumsuz yönde etkileyebilir (Sever,2002). Bu bakımdan, Türkçe öğretmeni adaylarına alan uzmanlarının kılavuzluğunda dilsel becerileri geliştirmeye yönelik eğitim ortamları yaratılmalıdır. Bu eğitim ortamlarında; dinleme, konuşma, okuma, yazma becerileri, uygun yöntem, teknik ve stratejilerin tanıklı̆ı̆nda öğretilmelidir (Çer, 2014: 93). Bununla birlikte, Türkçe öğretmenleri ve bu öğretmenleri yetiştiren öğretim elemanlarının Türkçe eğitiminde olduğu kadar Türkçe konusunda da yetkin olmaları gerekir. Türkçe eğitimi salt okuma-yazma, konuşma-dinleme eğitimi olarak değil; aynı zamanda düşünme ve estetik eğitimi olarak algılanmalı; edebiyat ve dilbilimden ayrı düşünülmemelidir (Börekçi, 2015: 412).

\section{Yöntem}

\section{Verilerin Toplanması}

Bu çalışmada, nitel bir yöntem olan doküman incelemesi kullanılmıştır. Doküman incelemesi, araştırılması hedeflenen olgu veya olgular hakkında bilgi içeren yazılı materyallerin çözümlenmesini kapsar. Araştırmacılarca elde edilen dokümanlar, nitel araştırmalarda etkili bir şekilde kullanılması gereken önemli bilgi kaynaklarıdır (Yıldırım ve Şimşek, 2011:188). Bu yünüyle, ilk olarak "Öğrenci Seçme ve Yerleştirme Sistemi Merkezi" (ÖSYS) 2015 yılı yükseköğretim programları ve kontenjanları kılavuzu incelenerek "Türkçe Öğretmenliği"ne sahip 62 üniversite belirlenmiştir. Ikinci olarak, belirlenen üniversitelere "Yüksek Öğretim Kurulu" (YÖK)'ün bilgisunar adresinden ulaşılarak bölümlerdeki öğretim 
elemanlarına ilişkin araştırma kapsamında ele alınan bilgilere ulaşılmıştır. Üçüncü olarak, YÖK'ün bilgisunar adresinden öğretim elemanlarına ilişkin bilgiler, "Yüksek Öğretim Kurulu Ulusal Tez Merkezi"nden elde edilen verilerle de desteklenmiştir. Ancak "Adnan Menderes Üniversitesi"nde Türkçe eğitimi bölümü olmasına karşın bölümün akademik kadrosu hakkında yeterli bilgi alınamadığından dolayı bu üniversite incelemeye alınmamıştır. Son olarak, araştırmaya ile ilgili kodlamaların nesnelliğini sağlamak amacıyla, araştırma konusuna aşina olmayan nitel araştırma ve doküman incelemede deneyimli bir öğretim görevlisine kodlamalar yeniden yaptırılmıştır. Araştırmacı ve öğretim görevlisi tarafından gerçekleştirilen sınıflandırmalar karşılaştırılmış ve farklı sınıflandırmalarda bir uzlaşmaya varılarak veriler son biçimine getirilmiştir.

\section{Verilerin Çözümlenmesi}

Bu çalışmada, içerik çözümlemesi türlerinden sıklık çözümlemesi tekniği uygulanmıştır. İ̧̧erik çözümlemesi, var olan bilgilerin temel içeriklerinin ve içerdikleri iletilerin özetlenmesi, karşılaştırılması ya da başka bir biçime dönüştürülmesi işlemidir (Driskove Maschi, 2015). İçerik çözümlemesi türünden sıklık çözümlemesinde ise birimlerin nicel olarak görünme sıklığı ortaya konur (Tavşancıl ve Aslan, 2001). Bu yönüyle, bu araştırmada Türkçe eğitimi bölümlerindeki öğretim elemanlarının Türkçe eğitimcisi olup olmadıklarına yönelik inceleme yapılmıştır. Bu inceleme, öncelikle üniversitelerin Türkçe eğitimi bölümlerinde yer alan öğretim elemanlarının nitelikleri göz önünde bulundurularak gerçekleştirilmiştir. Bunun için ilk olarak, Türkçe eğitimi bölümlerinde yer alan öğretim elemanlarının üniversitelere göre dağııımları ortaya çıkarılmıştır. İkinci olarak, öğretim elemanlarının uzmanlık alanlarına göre durumları belirlenerek akademik unvan ve cinsiyete göre sıklıkları saptanmıştır. Üçüncü olarak, Türkçe eğitimi bölümlerinde yer alan öğretim elemanlarının Türkçe eğitimcisi olup olmadıklarına yönelik olarak inceleme yapılmıştır. Son olarak ise, bu bölümlerde yer alan Türkçe eğitimcilerinin akademik unvan ve cinsiyetlere göre sıklıkları verilmiştir. Bu çalışma ile ilgili yapılan bütün sıklık ve yüzdeler SPSS 23'e girilerek gerçekleştirilmiştir.

\section{Bulgular}

Tablo 1'de, Türkçe eğitimi bölümlerinde yer alan öğretim elemanlarının üniversitelere göre dağılımları incelendiğinde, en fazla "Gazi Üniversitesi" 14 (\% 4.2), "Mustafa Kemal Üniversitesi" 10 (\% 3.0), "Ankara Üniversitesi" 9 (\% 2.7), "Çanakkale Onsekiz Mart Üniversitesi" 9 (\% 2.7), "Pamukkale Üniversitesi" 9 (\% 2.7), "Yıldız Teknik Üniversitesi" 9 (\% 2.7), "Abant İzzet Baysal Üniversitesi" 8 (\% 2.4), "Atatürk Üniversitesi" 8 (\% 2.4), "Giresun Üniversitesi" 8 (\% 2.4, "Inönü Üniversitesi" 8 (\% 2.4), "Konya Necmettin Erbakan Üniversitesi" 8 (\% 2.4), "Uludağ Üniversitesi" 8 (\% 2.4); en az ise, "Dicle Üniversitesi" 2 (\% 0.6), "Muş Alpaslan Üniversitesi" 2 (\% 0.6), "Afyon Kocatepe Üniversitesi" 3 (\% 0.9), "Adıyaman Üniversitesi" 3 (\% 0.9), "Amasya Üniversitesi" 3 (\% 0.9), "Başkent Üniversitesi" 3 (\% 0.9), "Bayburt Üniversitesi" 3 (\% 0.9), "Celal Bayar Üniversitesi" 3 (\% 0.9), "Istanbul Aydın Üniversitesi" 3 (\% 0.9), "Kilis 
7 Aralık Üniversitesi" 3 (\% 0.9), "Kocaeli Üniversitesi" 3 (\% 0.9) öğretim elemanına sahip olduğu belirlenmiştir. Bununla birlikte, Türkçe eğitimi bölümlerinin 37'sinde öğretim elemanlarının sayısının 5 ve üstünde olması, bu bölümlerin öğretim elemanı bakımından yeterli olduğunu; 24'ünde ise öğretim elemanlarının sayısının 4 ve altında olması bu bölümlerin öğretim elemanı bakımından yeterli olmadığını ortaya koymaktadır.

Tablo1. Türkçe Eğitimi Bölümlerinde Yer Alan Öğretim Elemanlarının Üniversitelere Göre Dağılımları

\begin{tabular}{|c|c|c|c|c|}
\hline \multirow[t]{2}{*}{ Üniversite } & \multicolumn{2}{|c|}{$\begin{array}{l}\text { Öğretim } \\
\text { Elemanları }\end{array}$} & \multicolumn{2}{|c|}{$\begin{array}{c}\text { Türkçe } \\
\text { Eğitimcisi }\end{array}$} \\
\hline & $f$ & $\%$ & $f$ & $\%$ \\
\hline Abant İzzet Baysal & 8 & 2.4 & 6 & 4.9 \\
\hline Adıyaman & 3 & 0.9 & 2 & 1.6 \\
\hline Afyon Kocatepe & 3 & 0.9 & - & - \\
\hline Ağrı Ibrahim Çeçen & 6 & 1.8 & 4 & 3.3 \\
\hline Ahi Evren & 7 & 2.1 & 2 & 1.6 \\
\hline Akdeniz & 5 & 1.5 & 2 & 1.6 \\
\hline Aksaray & 5 & 1.5 & 1 & 0.8 \\
\hline Amasya & 3 & 0.9 & 1 & 0.8 \\
\hline Ankara & 9 & 2.7 & 1 & 0.8 \\
\hline Artvin Çoruh & 5 & 1.5 & 1 & 0.8 \\
\hline Atatürk & 8 & 2.4 & - & - \\
\hline Balıkesir & 6 & 1.8 & 1 & 0.8 \\
\hline Bartın & 4 & 1.2 & - & - \\
\hline Başkent & 3 & 0.9 & 1 & 0.8 \\
\hline Bayburt & 3 & 0.9 & 1 & 0.8 \\
\hline Bülent Ecevit & 5 & 1.5 & 3 & 2.4 \\
\hline Canik Başarı & 4 & 1.2 & - & - \\
\hline Celal Bayar & 3 & 0.9 & - & - \\
\hline Cumhuriyet & 4 & 1.2 & - & - \\
\hline Çanakkale Onsekiz Mart & 9 & 2.7 & 6 & 4.9 \\
\hline Çukurova & 5 & 1.5 & - & - \\
\hline Dicle & 2 & 0.6 & - & - \\
\hline Dokuz Eylül & 6 & 1.8 & 2 & 1.6 \\
\hline Dumlupınar & 4 & 1.2 & 3 & 2.4 \\
\hline Ege & 4 & 1.2 & 1 & 0.8 \\
\hline Erciyes & 5 & 1.5 & 2 & 1.6 \\
\hline Erzincan & 8 & 2.4 & - & - \\
\hline Firat & 4 & 1.2 & 1 & 0.8 \\
\hline Gazi & 14 & 4.2 & 5 & 4.1 \\
\hline Gaziantep & 7 & 2.1 & 5 & 4.1 \\
\hline Gaziosman Paşa & 4 & 1.2 & 2 & 1.6 \\
\hline Giresun & 8 & 2.4 & 3 & 2.4 \\
\hline İnönü & 8 & 2.4 & 3 & 2.4 \\
\hline İstanbul Aydın & 3 & 0.9 & - & - \\
\hline İstanbul Sabahattin Zaim & 4 & 1.2 & 2 & 1.6 \\
\hline İstanbul & 6 & 1.8 & 1 & 0.8 \\
\hline Kafkas & 7 & 2.1 & 4 & 3.3 \\
\hline Karadeniz Teknik & 4 & 1.2 & 1 & 0.8 \\
\hline Kastamonu & 4 & 1.2 & - & - \\
\hline Kırıkkale & 6 & 1.8 & 2 & 1.6 \\
\hline Kilis 7 Aralık & 3 & 0.9 & 2 & 1.6 \\
\hline Kocaeli & 3 & 0.9 & - & - \\
\hline
\end{tabular}


Tablo 1. (Devamı) Türkçe Eğitimi Bölümlerinde Yer Alan Öğretim Elemanlarının Üniversitelere Göre Dağılımları

\begin{tabular}{lcccc} 
Konya Necmettin Erbakan & 8 & 2.4 & 4 & 3.3 \\
Marmara & 6 & 1.8 & 1 & 0.8 \\
Mehmet Akif Ersoy & 4 & 1.2 & 3 & 2.4 \\
Mersin & 5 & 1.5 & 1 & 0.8 \\
Mevlana & 5 & 1.5 & 1 & 0.8 \\
Muğla Sıtkı Koçman & 7 & 2.1 & 3 & 2.4 \\
Mustafa Kemal & 10 & 3.0 & 7 & 5.7 \\
Muş Alpaslan & 2 & 0.6 & - & - \\
Niğde & 6 & 1.8 & 5 & 4.1 \\
Ondokuz Mayıs & 4 & 1.2 & - & - \\
Pamukkale & 9 & 2.7 & 1 & 0.8 \\
Recep Tayyip Erdoğan & 5 & 1.5 & 4 & 3.3 \\
Sakarya & 7 & 2.1 & 1 & 0.8 \\
Siirt & 4 & 1.2 & 3 & 2.4 \\
Trakya & 5 & 1.5 & 1 & 0.8 \\
Uludağ & 5 & 2.4 & - & - \\
Uşak & 4 & 1.2 & 2 & 1.6 \\
Yıldız Teknik & 5 & 4.9 \\
Yüzüncü Yıl & 5 & 2.7 \\
Toplam & 5 & 6 & 100 \\
\hline
\end{tabular}

*Yüzdeler, kendi içinde ayrı olarak değerlendirmesini vermektedir.

Tablo 1'de, Türkçe eğitimcisi olan öğretim elemanlarının üniversitelere göre dağılımları incelendiğinde ise, en fazla "Mustafa Kemal Üniversitesi" 7 (\% 5.7), "Abant İzzet Baysal Üniversitesi" 6 (\% 4.9), "Çanakkale Onsekiz Mart Üniversitesi" 6 (\% 4.9), "Yıldız Teknik Üniversitesi" 6 (\% 4.9), "Gazi Üniversitesi" 5 (\% 4.1), "Gaziantep Üniversitesi" 5 (\% 4.1), "Niğde Üniversitesi" 5 (\% 4.1); en az ise, "Aksaray Üniversitesi" 1 (\% 0.8), "Amasya Üniversitesi" 1 (\% 0.8), "Ankara Üniversitesi" 1 (\% 0.8), "Artvin Çoruh Üniversitesi" 1 (\% 0.8), "Balıkesir Üniversitesi" 1 (\% 0.8), "Başkent Üniversitesi" 1 (\% 0.8), "Bayburt Üniversitesi" 1 (\% 0.8), "Ege Üniversitesi" 1 (\% 0.8), "Fırat Üniversitesi" 1 (\% 0.8), "Istanbul Üniversitesi" 1 (\% 0.8), "Karadeniz Teknik Üniversitesi" 1 (\% 0.8), "Marmara Üniversitesi" 1 (\% 0.8), "Mersin Üniversitesi" 1 (\% 0.8), "Mevlana Üniversitesi" 1 (\% 0.8), "Pamukkale Üniversitesi" 1 (\% 0.8), "Sakarya Üniversitesi" 1 (\% 0.8) ve "Trakya Üniversitesi" 1 (\% 0.8) olduğu görülmektedir. Bununla birlikte, 17 üniversitede 1 'er tane, 10 üniversitede 2'şer tane Türkçe eğitimcisinin olduğu ve 15 üniversitede Türkçe eğitimcisinin olmadığı görülmektedir. Genel olarak ise, Türkçe eğitimcilerinin bölüm içindeki sayısının ( $n=123$ ) Türkçe eğitimi bölümlerinde yer alan öğretim elemanlarıyla ( $n=335$ ) karşılaştırıldığında oldukça az olduğu belirlenmiştir.

Tablo 2'de, Türkçe eğitimi bölümlerinde yer alan öğretim elemanlarının uzmanlık alanlarına göre dağııımları incelendiğinde, en fazla "Türk Dili ve Edebiyatı" 150 (\% 44.8), "Türkçe Eğitimi" 123 (\% 36.7), "Dilbilim" 15 (\% 4.5), "Yeni Türk Edebiyatı" 13 (\% 3.9) ve "Eski Türk Edebiyatı" 9 (\% 2.7); en az ise, "Türk Dili" 1 (\% 0.3), "Edebiyat Eğitimi" 1 (\% 0.3) ve "Yeni Türk Dili" 5 (\% 0.3) olduğu görülmektedir. Alan dışı olarak ise, Tarih 1 (\% 0.3), "ilköğretim" 1 (\% 0.3), "Güzel Sanatlar Eğitimi" 2 (\% 0.6), "Eğitim 
Bilimleri" 3 (\% 0.9), "Alman Dili ve Edebiyatı" 3 (\% 0.9) ve "Alman Dili Eğitimi" 1 (\% 0.3) uzmanlık alanlarında öğretim elemanlarının olduğu saptanmıştır.

Tablo 2. Türkçe Eğitimi Bölümlerinde Yer Alan Öğretim Elemanlarıın Uzmanlık Alanlarına Göre Dağılımları

\begin{tabular}{lcc}
\hline \multicolumn{1}{c}{ Uzmanlık Alanları } & \multicolumn{2}{c}{ Türkçe } \\
& Eğitimcisi \\
\cline { 2 - 3 } & $f$ & $\%$ \\
\hline Yeni Türk Edebiyatı & 13 & 3.9 \\
Yeni Türk Dili & 5 & 1.5 \\
Türkçe Eğitimi & 123 & 36.7 \\
Türk Dili ve Edebiyatı & 150 & 44.8 \\
Türk Dili & 1 & 0.3 \\
Tarih & 1 & 0.3 \\
Ilköğretim & 1 & 0.3 \\
Halk Edebiyatı & 7 & 2.1 \\
Güzel Sanatlar Eğitimi & 2 & 0.6 \\
Eski Türk Edebiyatı & 9 & 2.7 \\
Eğitim Bilimleri & 3 \\
Edebiyat Eğitimi & 1 & 0.9 \\
Dilbilim & 15 & 0.3 \\
Alman Dili ve Edebiyatı & 4.5 \\
Alman Dili Eğitimi & 3 \\
Toplam & 1 & 0.9 \\
\hline
\end{tabular}

Tablo 3'te, Türkçe eğitimi bölümlerinde yer alan öğretim elemanlarının unvanlarına göre dağılımları incelendiğinde, "Prof. Dr." 57 (\% 17), "Doç. Dr." 80 (\% 23.9), "Yrd. Doç. Dr." 194 (\% 57.9) ve "Dr." 4 (\% 1.2) olduğu belirlenmiştir. "Yrd. Doç. Dr." unvanına sahip öğretim elemanlarının 194 (\% 57.9) oranında olması, bu unvana yönelik olarak sıklığı ortaya koymaktadır. Bununla birlikte, Türkçe eğitimi bölümlerinde yer alan Türkçe eğitimcisi olan öğretim elemanlarının en fazla "Yrd. Doç. Dr." 73 (\% 59.3) ve "Doç. Dr." 43 (\% 35.0); en az ise, "Prof. Dr." 6 (\% 4.9) ve "Dr." 1 (\% 0.8) unvanında olduğu belirlenmiştir. Başka bir söyleyişle, bu bölümlerde Türkçe eğitimcisi olan "Prof. Dr." 6 (\% 4.9) sayısının oldukça az olduğu, "Doç. Dr." 43 (\% 35.0) sayısında da artış olduğu görülmektedir.

Tablo 3. Türkçe Eğitimi Bölümlerinde Yer Alan Öğretim Elemanlarının Unvanlarına Göre Dağılımları

\begin{tabular}{lcccc} 
& \multicolumn{2}{c}{$\begin{array}{c}\text { Diğer Alan } \\
\text { Uzmanları }\end{array}$} & \multicolumn{2}{c}{$\begin{array}{c}\text { Türkçe } \\
\text { Eğitimcisi }\end{array}$} \\
\cline { 2 - 5 } & $f$ & 17 & $f$ & $\%$ \\
\hline Prof. Dr. & 57 & 6 & 4.9 \\
Doç. Dr. & 80 & 23.9 & 43 & 35.0 \\
Yrd. Doç. Dr. & 194 & 57.9 & 73 & 59.3 \\
Dr. & 4 & 1.2 & 1 & 0.8 \\
Toplam & & & 123 & 100 \\
\hline
\end{tabular}


Tablo 4'te, Türkçe eğitimi bölümlerinde yer alan öğretim elemanlarının cinsiyetlerine göre dağılımları incelendiğinde, erkeklerinin sayısının 240 (\% 71.6) kadınlara oranla 95 (\% 28.4) oldukça fazla olduğu görülmektedir. Bununla birlikte, Türkçe eğitimcisi olan öğretim elemanlarının cinsiyetlere göre dağılımları incelendiğinde ise, erkeklerinin sayısının 86 (\% 69.9) kadınlara oranla 37 (\% 30.1) oldukça fazla olduğu görülmektedir. Türkçe eğitim bölümlerinde görev yapan kadın öğretim elemanları 95 (\% 28.4) ile Türkçe eğitimcisi olan kadın öğretim elemanları 37 (\% 30.1) karşılaştırıldığında bölümde, Türkçe eğitimcisi olan kadın öğretim elemanı sayısının oldukça az olduğu belirlenmiştir.

Tablo 4. Türkçe Eğitimi Bölümlerinde Yer Alan Öğretim Elemanlarının Cinsiyetlerine Göre Dağılımları

\begin{tabular}{lcccc}
\hline \multirow{2}{*}{ Cinsiyet } & \multicolumn{2}{c}{$\begin{array}{c}\text { Diğer Alan } \\
\text { Uzmanları }\end{array}$} & \multicolumn{2}{c}{$\begin{array}{c}\text { Türkçe } \\
\text { Eğitimcisi }\end{array}$} \\
\cline { 2 - 5 } & $f$ & 28.4 & $f$ & $\%$ \\
\hline Kadın & 95 & 71.6 & 37 & 30.1 \\
Erkek & 240 & & 86 & 69.9 \\
Toplam & & 100 & 123 & 100 \\
\hline
\end{tabular}

\section{Tartışma}

Türkiye'de 193 üniversite içinde toplam sayısının 62 olduğu Türkçe eğitimi bölümlerinde yer alan öğretim elemanlarından ( $n=335$ ) salt 123 (\% 36.7)'ünün Türkçe eğitimcisi, 150 (\% 44.8)'sinin Türk Dili ve Edebiyatı uzmanı ve 62 (\% 18.5)'sinin diğer alan uzmanlarından oluşması, Türkçe öğretmeni adaylarının lisans eğitimi sırasında yeterli sayıda Türkçe eğitimcisiyle karşılaşmadığını ortaya koymaktadır. Özellikle 17 üniversitede 1'er tane, 10 üniversitede 2'şer tane Türkçe eğitimcisinin olması ve 15 üniversitede Türkçe eğitimcisinin olmaması, Türkçe öğretmeni adaylarının Türkçe öğretimine yönelik anlayışlarını etkileyebilir. Çünkü bölümde yer alan, alan eğitimi ile ilgili derslere alan dışı öğretim elemanlarının girmesi hem öğrencinin akademik başarısını etkileyebilir hem de alan eğitimine yönelik derslerde istenilen verimin alınamamasına yol açabilir. Yapılan araştırmalar, öğretmen adaylarının akademik başarılarının, özyeterlik inançlarının ve öğretmenlik mesleğine yönelik tutumlarının, öğretim üyelerinin niteliğiyle doğrudan ilişkili olduğunu ortaya koymaktadır (Ateş, 2015; Baştürk, 2011; Ekinci ve Burgaz, 2007; Özçakır Sümen ve Çağlayan, 2013; Saracaloğlu, Bozkurt, Serin ve Serin, 2004). Bu yönüyle, Türkçe öğretmeni adayının lisans eğitiminin niteliği, Türkçe öğretimini amaca uygun olarak yapılandırmadaki başarısını etkileyecek bir değişken olarak düşünülmelidir.

Türkçe eğitimi bölümlerinde yer alan öğretim elemanları unvanlarına göre incelendiğinde, “Prof. Dr." 57 (\% 17)'un salt 6 (\% 4.9)'sinin; "Doç. Dr." 80 (\% 23.9)'un salt 43 (\% 35.0)'ünün; "Yrd. Doç. Dr." 194 (\% 57.9)'un salt 73 (\% 59.3)'ünün Türkçe eğitimcisi olduğu görülmektedir. Bu durum, öğretmen adaylarının Türkçe eğitimcisi olan "Prof. Dr." 6 (\% 4.9) ile karşılaşma oranının oldukça düşük olduğunu; "Doç. Dr." 43 (\% 35.0) karşılaşma oranın ise biraz daha fazla olduğunu göstermektedir. Bununla birlikte, 
bu durum öğretmen adaylarının alan eğitiminde en üst düzeyde yetkinleşmiş öğretim elemanlarından çok fazla ders almadıklarını da ortaya koymaktadır. Daha açık bir söyleyişle, Türkçe öğretiminde öğretmen adayının yeterli düzeyde alan eğitimcisiyle karşılaşmaması, onların dilsel becerilerinin geliştirilmesinde çocuğun yaş ve gelişim düzeyinden hareket edilmesine, nitelikli çocuk edebiyatı yapıtlarının çocuk gerçekliğine uygun ve çocuğa göre olmasına (Çer, 2014, 2016a, 2016b, 2016c), işitsel, görsel ve dokunsal araç ve gereçlerin tanıklığında çok uyaranlı eğitim ortamlarının yaratılmasına (Turhan, 2016), sınıf ortamının "U" biçiminde düzenlenerek herkese eşit olanakların sağlanmasına (Sever, 2008), her nitelikli metnin içinde dilbilgisi konularını taşıdığı düşüncesinden hareketle derslerin metin odaklı işlenmesine, dilsel becerilerin geliştirilmesiyle çocuğun kestirim yapmasına, çıkarımda bulunmasına, neden-sonuç ilişkisi kurmasına, karşılaştırma yapmasına, eleştirel düşünmesine ve yaratıcı olmasına (Aslan, 2010) yönelik olarak bilgi ve becerileri tam anlamıyla içselleştirememesine yol açabilir. Çünkü Türkçe öğretmen adayları, salt ders kitaplarından elde ettiği bilgilerle Türkçeye yönelik olarak öğrenme ve öğretme sorumluluklarını yerine getiremeyebilir (Çer, 2011; Canlı, 2015: 117; Kaya, 2006: 90; Çetinkaya ve Uzun, 2014; Aslan ve Doğu, 2016: 22). Bu yönüyle, öğretmenlik ile ilgili bilgi ve becerilerinin üst düzey geliştiği ve alan bilgisinin yeterli olduğu öğretim elemanlarının, öğretmen adaylarının Türkçe öğretiminin niteliğini etkileyen değişkenleri etkili bir biçimde öğrenmesine katkı sağlamaları gerekir.

Güzel, Kurudayıoğlu ve Tüzel (2010: 460) ile Kurudayıoğlu ve Yılmaz'ın (2015: 370) yaptıkları araştırma sonuçlarıyla bu araştırmanın sonuçları karşılaştırıldığında, 2010 yılında Türkçe eğitimi bölümlerinde görev yapan 203 öğretim elemanının 47 (\% 23)'si ile 2015 yılında 280 öğretim elemanının 100 (\% 35)'ü Türkçe eğitimcisiyken; 2016 yılında 335 öğretim elemanının 123 (\% 36.7)'ünün Türkçe eğitimcisi olması ve 2010 yılında 10 (\% 19.5) üniversitede salt 1'er tane olan Türkçe eğitimcisinin 2015 yılında 12 (\% 23.4) üniversitede ve 2016 yılında 17 (\% 27.8) üniversitede 1'er tane olması, bu bölümlerde hem öğretim kadrosuna hem de Türkçe eğitimcisine yönelik artış olduğunu ortaya koymaktadır. Bununla birlikte, 2010 yılında 26 (\% 51) üniversitede Türkçe eğitimcisine rastlanmazken; bu sayının 2015 yılında 19 (\% 37)'a ve 2016 yılında ise 15 (\% 24.5)'e düşmesi, alan eğitimi açısından oldukça önemlidir. Bütün bu bulgular sonucunda, Türkçe eğitimi bölümlerinde Türkçe eğitimcilerine yönelik artışın olması hem Türkçe öğretiminin hem de öğretmen adayının niteliğini etkileyebilir (Sever, 2003).

Türkçe, Matematik, Fen Bilgisi ve Müzik eğitimi bölümlerinde, öğretmen adaylarının öğretim elemanlarını bilgi ve beceri yönünden, ölçme ve değerlendirme konusunda, öğretim yöntem, teknik ve stratejileri kullanma becerileri ve öğrenme-öğretme sürecinde etkili olan uygulamalara yer vermeleri açısından yeterli bulmamaları (Baştürk, 2011; Yeşil ve Özbek, 2008; Erginer ve Dursun, 2005; Arslantaş, 2011: 502; Şen ve Erişen, 2002; Arslantaş, Cinoğlu ve Yıldız, 2013: 8; Aksu, Çivitçi ve Duy, 2008; Murat, 
Arslantaş ve Özgan, 2006: 271; Köseoğlu, 1992: 74; Arslantaş, Cinoğlu ve Yıldız, 2013: 10), öğretim elemanlarının akademik yeterliğinin, öğretmenlik meslek ve genel kültür bilgisinin yeterli olmamasıyla birlikte (Arslantaş, Cinoğlu ve Yıldız, 2013: 8), alan ve alan eğitimi ile ilgili derslere başka alanlardan öğretim elemanlarının girmesinden kaynaklanabilir (Erginer, 1995: 36; Erginer, Erginer ve Bedir, 2009: 94). Bu yönüyle, Türkçe eğitimi bölümlerinde Türkçe eğitimcilerinin oldukça az olması ( $n=123$ ) ve alan eğitimcisi olmayan öğretim elemanlarının çokluğu $(n=212)$, alan eğitimi ile ilgili derslere başka alanlardan öğretim elemanlarının girdiğini ortaya koymaktadır. Bu durum, Türkçe öğretiminin sorunlarının başat nedeni olarak da görülebilir. Çünkü öğretmen adaylarının alan eğitimi ile ilgili konularda yetkinleşmesi (Akgöl, 1994, Bozdoğan, 2004; Tonbul, 2008; Tunca, Oğuz, Şahin ve Güner, 2015; Tutkun ve Gür Erdoğan, 2012; Ateş, 2015), öğretmen eğitimi veren kurumların ve alanlarında uzman öğretim elemanlarının sorumluluğundadır (Kırkkılıç ve Maden, 2010).

Bu araştırmanın ilk sınırlılığı, Türkçe eğitimi bölümlerindeki öğretim elemanları üzerinde gerçekleştirilmiş olmasıdır. Bu nedenle, bu araştırmanın farklı bölümlerde yer alan öğretim elemanlarına yönelik olarak çalışma grubu arttırılarak başka çalışmalarla da desteklenmesi gerekmektedir. İkinci olarak ise, bu araştırmada öğretim elemanları salt Türkçe eğitimcisi olup olmadığı, unvan ve cinsiyet açısından değerlendirilmiştir. İlerleyen çalışmalarda, öğretim elemanları üzerinde farklı değişkenlere yönelik olarak araştırmaların yapılması gerekmektedir. Son olarak ise, bu araştırmada ne öğretim elemanları ne de öğretmen adayları üzerinde herhangi bir görüşme yapılmıştır. İlerleyen çalışmalarda, Türkçe eğitimi bölümlerinde görev yapan öğretim elemanları ve öğretmen adayları üzerlerinde görüşmeleri kapsayacak biçimde çalışmalar da yapılabilir.

Sonuç olarak, bu araştırmada Türkçe eğitimi bölümlerinde yer alan Türkçe eğitimcilerinin sayısının oldukça yetersiz olduğu ortaya çıkarılmıştır. Bu araştırmanın sonuçlarından yola çıkarak sunulabilecek öneri ise, Türkiye'nin farklı bölgelerinden seçilecek üniversitelerin Türkçe eğitimi bölümlerinde yer alan Türkçe eğitimcilerinin yeterlikleri üzerinde çalışmaların yapılmasıdır. Böylelikle, alan eğitimcilerinin hem akademik düzeyleri ortaya konabilir hem de öğretmen adayı üzerindeki etkisi açığa çıkarılabilir.

\section{Kaynaklar}

Akgöl, H. (1994). Eğitim fakültelerindeki öğretim elemanları ve öğrencilerin ideal bir öğretim elemanının nitelikleri hakkındaki görüşleri ile kendi kurumlarındaki öğretim elemanlarının bu niteliklere uygunluklarının karşılaştırılması. Yayınlanmamış Doktora Tezi. Dokuz Eylül Üniversitesi Sosyal Bilimler Enstitüsü, İzmir.

Aksu, M. B. ve Çivitçi, A., Duy, B. (2008). Yükseköğretim öğrencilerinin öğretim elemanlarının ders uygulamaları ve sınıf içi davranışlarına ilişkin görüşleri. Inönü Üniversitesi Eğitim Fakültesi Dergisi, 9(16), 17-42.

Arslantaş, H. í. (2011). Öğretim elemanlarının öğretim stratejileri-yöntem ve teknikleri, iletişim ve ölçme değerlendirme yeterliklerine yönelik öğrenci görüşleri. Mustafa Kemal Üniversitesi Sosyal Bilimler Enstitüsü Dergisi, 8(15), 487-506.

Arslantaş, H. i., Cinoğlu, M. ve Yıldız, M. A. (2013). Öğretim elemanlarının sınıf içi öğretim becerilerinin öğrenci görüşlerine göre değerlendirilmesi. Inönü Üniversitesi Eğitim Fakültesi Dergisi, 13(3), 1-20. 
Aslan, C. (2007a). Yazınsal nitelikli çocuk kitaplarının çocuğun okuduğunu anlama ve yazılı anlatım becerisine etkisi. Eğitim Araştırmaları, 27, 15-29.

Aslan, C. (2007b). Yazınsal nitelikli çocuk kitaplarının çocuğun gelişim sürecindeki yeri. Il. Ulusal Çocuk ve Gençlik Edebiyatı Sempozyumu, Gelişmeler-Sorunlar, Çözüm Önerileri (04-06 Ekim 2006). Sempozyum Kitabı, (s. 192-206). Ankara: Ankara Üniversitesi Basımevi.

Aslan, C. (2010). Düşünme becerilerini geliştirici dil ve edebiyat öğretimi ortamları -Bir eğitim durumu örneği Balıkesir Üniversitesi Sosyal Bilimler Enstitüsü Dergisi, 13(24), 127-152.

Aslan, C. ve Doğu, Y. (2016). Öğrencilerin ortaokul Türkçe ders kitaplarındaki metinlere ilişkin görüşleri. Akademik Araştırmalar Dergisi, 17(67), 1-30.

Ateş, M. (2015). Türkçe öğretmenliği lisans programlarının öğretmen yeterlikleri açısından incelenmesi. International Journal of Social Science, 41, 293-301.

Baştürk, S. (2011). Matematik öğretmen adaylarının eğitim fakültesindeki eğitim-öğretim sürecini değerlendirmeleri. Uluslararası insan Bilimleri Dergisi, 8(1), 58-94.

Bozdoğan, Z. (2004). Etkili öğretmenlik eğitimi. Ankara: Nobel Yayınları.

Börekçi, M. (2015). Bir bilim alanı olarak Türkçe ve Türkçe eğitimi. Erzincan Üniversitesi Sosyal Bilimler Enstitüsü Dergisi, 9(2), 405-414.

Canlı, S. (2015). Türkçe ders kitaplarına seçilecek metinlerin belirlenmesinde çocuğa görelik ilkesi. Journal of Language Education and Research, 1(1), 98-123.

Çer, E. (2011). İlköğretim 4. sınıf Türkçe ders kitaplarının çocuğa görelik ilkelerine göre incelenmesi. 20. Ulusal Eğitim Bilimleri Kurultayı. (8-10 Eylül 2011). Bildiri Özet Kitapçı̆̆ı. Burdur: Mehmet Akif Ersoy Üniversitesi Eğitim Fakültesi Yayını, s. 595-596.

Çer, E. (2014). Çocuk edebiyatı: 0-6 yaş çocuk kitaplarında çocuk gerçekliği ve çocuğa görelik. Ankara Üniversitesi Eğitim Bilimleri Enstitüsü, Ankara.

Çer, E. (2016a). Çocuk edebiyatı: 0-6 yaş çocuk kitaplarında çocuk gerçekliği ve çocuğa görelik. Ankara: Eğiten Kitap.

Çer, E. (2016b). Preparing for books children from birth to six: The approach of appropriateness for the child. Journal of Education and Practice, 7(6), 78-99.

Çer, E. (2016c). Preparing for books children from birth through six: A new children's reality approach. Universal Journal of Educational Research, 4(5), 1024-1036.

Çetinkaya, G. ve Uzun, L. (2014). Türkçe ders kitaplarındaki metinlerin okunabilirlik özellikleri. (Ed.: H. Ülper). Türkçe Ders Kitabı Çözümlemeleri. Ankara: PegemA Akademi.

Çotuksöken, Y. (2010). Uygulamalı Türkçe yazılı ve sözlü anlatım. İstanbul: Papatya Yayıncılık.

Dilidüzgün, S. (2003). Iletişim odaklı Türkçe derslerinde çocuk kitapları. İstanbul: Morpa Kültür Yayınları.

Drisko, J. ve Maschi, T. (2015). Content analysis. London: Oxford University Press.

Ekinci, C. E. ve Burgaz, B. (2007). Hacettepe üniversitesi öğrencilerinin bazı akademik hizmetlere ilişkin beklenti ve memnuniyet düzeyleri. Hacettepe Üniversitesi Eğitim Fakültesi Dergisi, 33, 120-134.

Erginer, E. (1995). illkokul öğretmenliği eğitiminde standartlar, uzmanlaşma ve yeni bir model önerisi. Çağdaş Eğitim Dergisi, 207, 34-40.

Erginer, E. ve Dursun F. (2005). Öğretim elemanlarının etkili öğretim becerilerinin geliştirilmesine yönelik görüşleri. Eğitim ve Bilim, 30(135), 11-22.

Erginer, E., Erginer, A., Bedir, G. (2009). Eğitim fakültelerinde görevli öğretim elemanlarının akademik kökenleri ve öğretmen yeterliklerinin incelenmesi üzerine bir inceleme. Abant izzet Baysal Üniversitesi Dergisi, 9(2), 93-108.

Ergün, M., Duman, T., Kıncal, R. K. ve Arıbaş, S. (1999). İdeal bir öğretim elemanının özellikleri. Afyon Kocatepe Üniversitesi Sosyal Bilimler Dergisi, 3, 1-11.

Ertürk, S. (1993). Eğitimde program geliştirme. Ankara: Meteksan Yayınları.

Göçer, A. (2014). Yazma eğitimi. Ankara: PegemA Yayıncılık.

Göğüş, B. (1993). Türkçe öğretimine genel bir bakış. Ferhan Oğuzkan (Yay. Haz.). ilköğretim okullarında Türkçe öğretimi ve sorunları. Ankara: Türk Eğitim Derneği Yayınları.

Güzel, A., Kurudayıoğlu, M., Tüzel, S. (2010). Türkçe öğretmenliği bölümlerinin akademik yapısına ilişkin bir değerlendirme. III. Uluslararası Dünya Dili Türkçe Sempozyumu Bildiri Kitabı (16-18 Aralık 2010). İmir: Kanyılmaz Matbaası.

Karamustafaoğlu, O. ve Özmen, H. (2004). Toplumumuzda ve öğretmen adayları arasında öğretmenlik mesleğine verilen değer üzerine bir araştırma. Değerler Eğitimi Dergisi, 2(6), 35-49.

Kavcar, C. (1999). Nitelikli öğretmen sorunu. Eğitimde Yansımalar: V. 21. Yüzyıl Eşiğinde Türk Eğitim Sistemi Ulusal Sempozyum Bildirileri. (s. 267-279). Öğretmen Hüseyin Hüsnü Tekışık Eğitim Araştırma -Geliştirme Merkezi Yayını. 
Kavcar, C. (2002a). Türkçenin güncel sorunları. Bilim ve Aklın Aydınlığında Eğitim, 27, 13-17.

Kavcar, C. (2002b). Cumhuriyet döneminde dal öğretmeni yetiştirme. Ankara Üniversitesi Eğitim Bilimleri Fakültesi Dergisi, 35(1-2), 1-14.

Kaya, Z. (2006). Türkçe ders kitaplarında metinlerin türsel/yazınsal niteliği. II. Ulusal Çocuk ve Gençlik Edebiyatı Sempozyumu. (Yay. Haz.: S. Sever) Ankara Üniversitesi Çocuk ve Gençlik Edebiyatı Uygulama ve Araştırma Merkezi, No: 4, s. 83-89.

Kırkkılıç, A. ve Maden, S. (2010). İlköğretim ve lisans programlarındaki değişiklikler sonrasında Türkçe öğretmenliği mesleğinin ve Türkçe eğitimi bölümlerinin durumu. TÜBAR, XXVII, 477-502.

Köseoğlu, K. (1992). ilköğretime öğretmen yetiştiren kurumlarda öğretim elemanı yeterliklerinin değerlendirilmesi. Yayınlanmamış Yüksek Lisans Tezi. Ankara Üniversitesi Sosyal Bilimler Enstitüsü, Ankara.

Kurudayıoğlu, M. ve Yılmaz, E. (2015). Türkçe eğitimi bölümlerinin akademik yapı açısından değerlendirilmesi. (Ed.: M. V. Coşkun vd.). Türkçenin eğitimi-öğretimine yönelik çalışmalar. (s. 362- 371). Ankara: PegemA Yayıncılık.

Küçükahmet, L. (1993). Öğretim ilke ve yöntemleri. Ankara: Gazi Kitabevi.

MEB (2015). Türkçe dersi öğretim programı (1-8. sınıflar). Ankara: T.C Milli Eğitim Bakanlığı, Talim ve Terbiye Kurulu Başkanlığı.

Milliyet (2006). Eğitim fakültelerinin yeniden yapılandırılmasında ilk aşama tamam. http://www.milliyet.com.tr/egitim-fakultelerinin-yeniden-gundem-2264110/ adresinden 26 Haziran 2016'da alınmıştır.

Murat, M., Arslantaş, H. İ. ve Özgan, H. (2006). Öğretim elemanlarının sınıf içi eğitim-öğretim etkinlikleri açısından değerlendirilmesi. G.Ü. Gazi Eğitim Fakültesi Dergisi, 26(3), 263-278.

Özbay, M. (2006). Türkçe özel öğretim yöntemleri I. Ankara: Öncü Kitap.

Özçakır Sümen, Ö. ve Çağlayan, K. T. (2013). Öğretmen adaylarının eğitim fakültesinden memnuniyet düzeyleri ve hayal ettikleri eğitim ortamı. Ondokuz Mayıs Üniversitesi Eğitim Fakültesi Dergisi, 32(2), 249-272.

Özdemir, E. (2002). Türkçenin en önemli sorunlarından biri dil kirlenmesidir. Bilim ve Aklın Aydınlığında Eğitim, 27, 8-12

Saracaloğlu, A. S., Bozkurt, N., Serin, O. ve Serin, U. (2004). Öğretmen adaylarının mesleğe yönelik tutumlarını etkileyen faktörler. Çağdaş Eğitim Dergisi, 29(311), 16-27.

Saylan, N. ve Uyangör, N. (1998). Öğrenci görüşlerine göre Necatibey eğitim fakültesi öğretim elemanlarında bulunan öğretmenlik niteliklerinin belirlenmesi. Balıkesir Üniversitesi Sosyal Bilimler Enstitüsü Dergisi, 1(2), 35-67.

Seferoğlu, S. S. (2004a). Öğretmen yeterlikleri ve mesleki gelişim. Bilim ve Aklın Aydınlığında Eğitim, 58, 40-45.

Seferoğlu, S. S. (2004b). Öğretmen adaylarının öğretmen yeterlikleri açısından kendilerini değerlendirmeleri. Hacettepe Üniversitesi Eğitim Fakültesi Dergisi, 26, 131-140.

Sever, S. (2002). Öğretim dili olarak Türkçenin sorunları ve öğretme-öğrenme sürecindeki etkili yaklaşımlar. Hüseyin Akbulut, Şükrü Haluk Akalın, Osman Güzel vd. (Düzenleme Kurulu). Türkçenin Dünü, Bugünü, Yarını. Uluslararası Bilgi Şöleni Bildiriler. Ankara: T. C. Kültür Bakanlığı Yayınları.

Sever, S. (2003). Türkçe öğretiminde yeni yapılanma çalışmaları. TÜBAR, XIII, 27-38.

Sever, S. (2008). Eğitim ve bilimde Türkçe. Inönü Üniversite Türkiye Cumhuriyeti'nin Kuruluşunun 100'üncü Yılında Eğitim Kurultayı, 100, 435-471.

Sever, S. (2011). Türkçe öğretimi ve tam öğrenme. Ankara: Anı Yayıncılık.

Sever, S., Kaya, Z. ve Aslan, C. (2011). Etkinliklerle Türkçe öğretimi. İzmir: Tudem Yayınları.

Şen, H. Ş., Erişen, Y. (2002). Öğretmen yetiştiren kurumlarda öğretim elemanlarının etkili öğretmenlik özellikleri. G.Ü. Gazi Eğitim Fakültesi Dergisi, 22(1), 99-116.

Şişman, M. (2009a). Öğretmen yeterliliklerini yeniden düşünmek. Türk Yurdu Dergisi, 29, 37-41.

Şişman, M. (2009b). Öğretmen yeterlilikleri: Modern bir söylem ve retorik. Inönü Üniversitesi Eğitim Fakültesi Dergisi, 10(3), 63-82.

Tavşancıl, E. ve Aslan, E. (2001). Sözel, yazılı ve diğer materyaller için içerik analizi ve uygulama örnekleri. İstanbul: Epsilon Yayıncılık.

Tonbul, Y. (2008). Öğretim üyelerinin performansının değerlendirilmesine ilişkin öğretim üyesi ve öğrenci görüşleri. Kuram ve Uygulamada Eğitim Yönetimi, 56, 633-662.

Tunca, N., Oğuz, A., Şahin, S. A. ve Güner, H. Ö. B. (2015). Qualities of ideal teacher educators. Turkish Online Journal of Qualitative Inquiry, 6(2), 122-148.

Turhan, H. (2016). Çok uyaranlı eğitim ortamlarının öğrencilerin okuduğunu anlama ve yazılı anlatım becerilerine etkisi. Yayımlanmamış Doktora Tezi. Ankara Üniversitesi Eğitim Bilimleri Enstitüsü, Ankara. 
Tutkun, Ö. F. ve Gür Erdoğan, D. (2012). Sakarya üniversitesi eğitim fakültesi öğrencilere göre öğrenme ve öğretme süreçlerinde öğretim elemanlarının yeterlikleri. Akademik Bakış Dergisi, 30,1-11.

Yeşil R. ve Özbek, R. (2008). Sosyal alanlar eğitimi bölümlerindeki “branş” öğretim elemanlarının sorulardan yararlanma yeterlikleri. Ahi Evran Üniversitesi Kırşehir Eğitim Fakültesi Dergisi, 9(3), 175-186.

Yıldırım, A. ve Şimşek, H. (2011). Nitel araştırma yöntemleri. Ankara: Seçkin Yayıncılık.

Yılman, M. (1992). Illköğretim okullarına öğretmen yetiştirme sorunu. Hacettepe Üniversitesi Eğitim Fakültesi Dergisi, 8, 263-267.

YÖK (2007). Eğitim fakültesi öğretmen yetiştirme lisans programları. http://www.yok.gov.tr/documents/10279/49665/turkce_ogretmenligi.pdf/d0d11c2d -bc83-4186-8717b33597eb8eb6 adresinden 28 Mayıs 2016'da alınmıştır.

YÖK (2015). Öğrenci seçme ve yerleştirme sistemi yükseköğretim programları ve kontenjanları kılavuzu http://dokuman.osym.gov.tr/pdfdokuman/2015/OSYS/2015 -OSYSKONTKILAVUZU01072015.pdf adresinden 05 Haziran 2016'da alınmıştır. 